\title{
PENGARUH KEPUASAN KERJA DAN MOTIVASI KERJA TERHADAP KINERJA DOSEN FAKULTAS EKONOMI DI PERGURUAN TINGGI SWASTA DI MAKASSAR
}

\author{
Mira Labi Bandhaso ${ }^{1}$, Natalia Paranoan ${ }^{1}$ \\ ${ }^{1}$ Dosen Jurusan Akuntansi Fakultas Ekonomi UKI Paulus Makassar
}

\begin{abstract}
This study aims to determine the effect of job satisfaction and motivation on the lecturer performance at private universities in Makassar. The research conducted on the lecturer of faculty of economics at three private universities in Makassar South Sulawesi by using mail survey and sending 150 questionnaires to the respondents. Sampling technique used in this study is random sampling. Data were collected at 101 and analyzed using multiple linear regression analysis. The analysis result showed that job satisfaction gives positive impact and significant on the performance of private university lecturers in Makassar, and motivation gives positive impact and significant on the performance of private university lecturers in Makassar. The results of multiple regression analysis showed motivation and job satisfaction simultaneously have positive and significant impact on the performance of private university lecturers in Makassar.
\end{abstract}

Keywords: Job Satisfaction, Motivation, Performance, Lecturer

\begin{abstract}
ABSTRAK
Penelitian ini bertujuan untuk menentukan pengaruh kepuasan kerja dan motivasi terhadap kinerja dosen di perguruan tinggi swasta di Makassar. Penelitian ini dilakukan pada dosen-dosen Fakultas Ekonomi di tiga perguruan tinggi swasta di Makassar Sulawesi Selatan melalui mail survey dan mengirimkan 150 kuesioner kepada responden. Data yang terkumpul adalah 101 dan dianalisis menggunakan teknik analisis regresi linier berganda. Hasil analisis menunjukkan bahwa kepuasan kerja berpengaruh positif dan signifikan terhadap kinerja dosen-dosen perguruan tinggi swasta di Makassar. Selain itu, hasil penelitian ini juga menunjukkan bahwa motivasi berpengaruh positif dan signifikan terhadap kinerja dosen-dosen perguruan tinggi swasta di Makassar. Hasil analisis regresi linier berganda menunjukkan bahwa kepuasaan kerja dan motivasi secara simultan berpengaruh positif dan signifikan terhadap kinerja dosen-dosen perguruan tinggi swasta di Makassar.
\end{abstract}

Kata kunci: Kepuasaan Kerja, Motivasi, Kinerja, Dosen

Jurnal Akun Nabelo: Jurnal Akuntansi Netral, Akuntabel, Objektif Volume 1/Nomor 2/Jan 2019 Jurusan Akuntansi FE-Universitas Tadulako

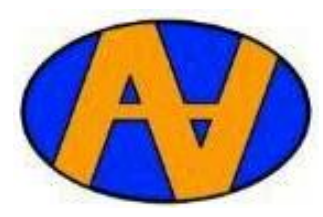




\section{A. PENDAHULUAN}

Manajemen sumber daya manusia yang dilaksanakan dengan baik akan memberikan kontribusi yang cukup besar dalam usaha mencapai sasaran organisasi atau perusahaan. Manajemen sumber daya manusia bertugas mempelajari dan mengelola unsur-unsur manusia dengan segala potensi yang dimiliki se-efektif mungkin sehingga dapat diperoleh sumber daya manusia yang memuaskan (satisfactory) bagi organisasi (Triton, 2005). Manajemen sumber daya manusia merupakan aktivitas pengembangan yang dilaksanakan agar sumber daya manusia di dalam organisasi dapat digunakan secara efektif untuk mencapai berbagai tujuan. Manusia merupakan sumber daya yang penting dalam organisasi, disamping itu efektivitas organisasi sangat ditentukan oleh manajemen sumber daya manusia (Sulistiyani \& Rosidah, 2005).

Dalam menghadapi era globalisasi dewasa ini, maka pengembangan sumber daya manusia sangat diperlukan. Demikian juga halnya setiap dosen sebagai komponen sumber daya manusia di perguruan tinggi harus memiliki kinerja yang baik dalam melaksanakan tri darma perguruan tinggi, antara lain meliputi: loyalitas, dedikasi, disiplin, tanggung jawab, dan motivasi kerja yang tinggi. Sumber daya manusia yang berkualitas sangat dibutuhkan oleh perguruan tinggi dalam melaksanakan tri darma perguruan tinggi, yaitu di bidang pendidikan dan pengajaran, penelitian, dan pengabdian kepada masyarakat. Sumber daya manusia yang terlibat di perguruan tinggi tersebut terdiri dari para dosen (tenaga akademik), karyawan (tenaga administratif), mahasiswa, dan para alumni yang merupakan satu sistem yang saling berkaitan dalam mengemban tri dharma perguruan tinggi tersebut. Sedangkan, perguruan tinggi sebagai pusat pembelajaran ingin mencetak sumber daya manusia yang berkualitas. Perguruan tinggi sebagai suatu organisasi memiliki unsur-unsur manusia (sumber daya manusia), falsafah, proses, dan tujuan.

Dalam penyelenggaraan sistem pendidikan tinggi di Indonesia dewasa ini masih dihadapkan kepada banyak persoalan atau kelemahan apabila dibandingkan dengan harapan (expectations) masyarakat (stakeholders) dan juga apabila dibandingkan dengan perguruan tinggi negara-negara lain yang masih sama-sama dalam kategori negara berkembang. Salah satu kelemahannya adalah rendahnya kinerja dosen karena berbagai faktor, baik faktor internal dosen sendiri maupun faktor eksternal atau faktor lingkungan (Isham, 2008). Mengenai gejala atau fenomena rendahnya kinerja dosen telah banyak diberitakan, baik melalui media cetak dalam rubrik "Surat Pembaca", melalui media televisi dan radio dalam forum interaktif dengan mahasiswa dan orang tua siswa maupun dalam seminar-seminar pada waktu kesempatan tanya-jawab. Bagi mahasiswa, rendahnya kinerja dosen dapat dirasakan langsung oleh mereka. Keluhan-keluhan yang sering diungkapkan mahasiswa terhadap kinerja dosen diantaranya adalah dosen kurang mempersiapkan materi perkuliahan yang mau diajarkan, sering tidak masuk kelas/tidak datang ke kampus, sering mendelegasikan tugas mengajar kepada para asisten, tidak membahas tugastugas dan latihan/ujian yang diberikan agar mahasiswa mengetahui dimana kesalahan atau kelemahan mereka, membuat ketentuan penilaian ujian yang berbeda-beda antara sesama dosen, dan susah dihubungi atau dijumpai apabila ingin berkonsultasi atau meminta penjelasan atas sesuatu hal (Isham, 2008).

Kinerja sebagian dosen masih rendah dan perlu ditingkatkan. Hal ini dapat ditunjukkan dengan adanya kehadiran dosen di dalam kelas belum maksimal, masih ada dosen yang lalai menjalankan tanggung jawabnya dalam mengajar. Walaupun aktivitas 
monitoring telah dijalankan, ditambah dengan pengalokasian insentif, namun kinerja sebagian dosen ternyata belum sesuai seperti yang diharapkan oleh lembaga. Di samping itu intensitas dosen di ruangan kelas belum berjalan merata. Masih ada saja dosen yang tidak maksimal memberikan kuliah khususnya dosen yang merangkap jabatan struktural di jurusan atau fakultas atau universitas. Kinerja dosen di perguruan tinggi swasta juga menunjukkan gejala-gejala yang kurang menggembirakan. Indikasi ini dapat dilihat melalui berbagai fakta misalnya: (i) Dosen mengajar kurang mencocokan dengan silabus yang diberikan; (ii) Media dan metode yang digunakan dalam proses belajar mengajar yang kurang bervariasi; (iii) Dosen mempunyai kecenderungan untuk mengajar materi pelajaran yang sama pada tahun ajaran berikutnya; (iv) Hasil penataran kurang disosialisasikan; dan (v) Jam perkuliahan dimulai kurang tepat waktu oleh sebagian dosen (Alhamda \& Sanusi, 2006).

Berdasarkan itu, penelitian ini bertujuan untuk menyelediki pengaruh kepuasan kerja dan motivasi terhadap kinerja dosen baik secara parsial maupun simultan. Temuan penelitian ini diharapkan dapat dimanfaatkan oleh perguruan tinggi dalam mengambil kebijakan terkait pengelolaan sumber daya manusia di perguruan tinggi.

\section{B. TELAAH PUSTAKA}

\section{B.1 Kepuasan Kerja}

Kepuasan kerja berkenaan dengan sikap seorang karyawan terhadap pekerjaan/tugasnya dalam organisasi. Kepuasan kerja adalah suatu sikap umum seseorang terhadap pekerjaannya (an individual general attitude toward his or her job) (Robbins, 2006). Apabila balas jasa yang diterima seorang karyawan sama dengan balas jasa yang diyakininya pantas diterima, maka akan timbul rasa kepuasan dalam diri karyawan tersebut. Sebaliknya apabila balas jasa yang mereka terima lebih kecil dari balas jasa yang mereka yakini pantas diterima, maka akan timbul rasa tidak puas terhadap tugas pekerjaan mereka. Ramaseshan (2006) mendefinisikan kepuasan kerja sebagai keterikatan seseorang dengan pekerjaannya (people's attachment to their work), dan ketidakpuasan kerja sebagai keterasingan seseorang dari pekerjaannya (people's allienation from their job).

Karyawan dengan kepuasan kerja yang tinggi mempunyai sikap (attitudes) yang positif terhadap pekerjaannya, sedangkan karyawan dengan kepuasan kerja yang rendah mempunyai sikap yang negatif terhadap tugas/pekerjaannya. Selanjutnya, kepuasan kerja mewakili sikap, bukan mewakili perilaku. Berdasarkan uraianuraian di atas, kepuasan kerja dosen untuk penelitian ini adalah rasa senang atau tidak senang seorang dosen terhadap pekerjaannya yang merefleksikan dimensi perasaan (adil, aman, dihargai, senang, menikmati, bersemangat, dan bangga), dimensi suasana kerja (dukungan atasan, hubungan dengan teman sekerja, lingkungan fisik kerja, kesempatan promosi), dan dimensi balas jasa (gaji, bonus, dan insentif).

\section{B.2 Motivasi Kerja}

Robbins (2006) mendefinisikan motivasi sebagai kondisi mental yang mendorong dilakukannya sesuatu tindakan dan memberikan kekuatan yang mengarah kepada pencapaian kebutuhan dan memberi kepuasan. Menurut Siagian (2005), terdapat korelasi positif antara motivasi dengan tujuan. Sekelompok orang, yang mengklaim satu kesatuan kerja mempunyai sasaran yang ingin dicapai, mempunyai motivasi kerja lebih tinggi daripada kelompok orang yang bekerja tanpa sasaran yang jelas. Seorang pemimpin harus mempunyai cara yang tepat untuk dapat memotivasi karyawan untuk dapat mencapai prestasi kerja yang tinggi. 
Motivasi adalah suatu konsep yang diutarakan sebagai kebutuhan (needs) dan rangsangan (incentive) yang tidak dapat dipisahkan karena dua hal tersebut saling bertiubungan. Motivasi adalah penyebab tindakan, yakni kondisi yang memulai tingkah laku atau kegiatan. Robbins (2006) memandang motivasi sebagai kesediaan untuk melakukan upaya yang tinggi ke arah tujuan-tujuan organisasi yang dikondisikan oleh kemampuan uniuk memenuhi kebutuhan individual. Motivasi adalah akibat dari interaksi antara individu dengan situasi yang ada. Motivasi kerja merupakan tingkah laku yang diarahkan untuk mencapai tujuan dimana di balik tingkah laku tersebut ada semacam kebutuhan, kerinduan dan keinginan. Kebutuhan mengandung arti adanya kekurangan dan kekurangan itu mungkin dapat dipuaskan bila tercapai tujuan yang telah ditetapkan. Kemauan dan keinginan mengandung arti adanya perasaan yang kuat.

\section{B.3 Kinerja}

Kinerja karyawan adalah proses yang mengukur seberapa baik seseorang karyawan melakukan pekerjaan yang ditugaskan. Kinerja juga dapat diartikan sebagai kegiatan atau aktivitas produktif seorang dosen dalam suatu periode yang telah berlalu yang mempunyai kontribusi terhadap pencapaian tujuan pengajaran. Kinerja seseorang merupakan kombinasi dari kemampuan, usaha dan kesempatan yang dapat dinilai dari hasil kerjanya. Bernardin dan Russel dalam Sulistiyani dan Rosidah (2005) menjelaskan kinerja merupakan catatan outcome yang dihasilkan dari fungsi pegawai atau kegiatan yang dilakukan selama periode waktu tertentu. Kinerja suatu jabatan secara keseluruhan sama dengan jumlah (rata-rata) dari kinerja fungsi pegawai atau kegiatan yang dilakukan. Kinerja seseorang merupakan kombinasi dari kemampuan, usaha dan kesempatan yang dapat dinilai dari hasil kerjanya. Berdasarkan itu, kinerja merupakan sesuatu yang penting dalam pencapaian tujuan, apakah itu tujuan pribadi (individual objectives), tujuan kelompok (group objectives), atau tujuan organisasi (organizational objectives). Drucker menyatakan bahwa sistem manajemen yang paling bertahan hidup akan bermasalah apabila manajemen hanya menekankan pada tujuan "keuntungan" semata karena akan mengarahkan para manajer untuk berusaha mendapatkan keuntungan jangka pendek dan tidak memikirkan keuntungan jangka panjang. Drucker (2004) mensyaratkan bahwa untuk kelangsungan hidup perusahaan, pemimpin perusahaan harus menetapkan beberapa tujuan sekaligus yang meliputi area-area yang kritis bagi operasi dan keberhasilan sistem manajemen.

Bertitik tolak dari rumusanrumusan yang telah dikemukakan di bagian awal dan kerangka konseptual yang dibangun, maka selanjutnya dikemukakan perumusan hipotesis sebagai berikut:

H1: Kepuasan kerja mempunyai pengaruh langsung secara signifikan terhadap kinerja dosen.

H2: Motivasi kerja mempunyai pengaruh langsung secara signifikan terhadap kinerja dosen.

H3: Kepuasan kerja dan motivasi kerja secara simultan mempunyai pengaruh langsung secara signifikan terhadap kinerja dosen.

\section{METODE PENELITIAN}

\section{C.1 Populasi dan Sampel}

Penelitian ini dilakukan pada dosen atau staf pengajar pada Fakultas Ekonomi di tiga perguruan tinggi swasta di Makassar yang terakreditasi A dan B dengan menggunakan mail survey yaitu dengan mengirimkan kuisioner melalui pos. Dalam hal ini yang dimaksudkan dengan terakreditasi A dan B adalah program studinya, dan bukan lembaganya (universitas dan sekolah tinggi). Adapun teknik sampling yang digunakan dalam penelitian ini adalah random 
sampling. Ukuran sampel (sampling size) ditentukan dengan mempertimbangkan proporsi jumlah dosen masing-masing unit perguruan tinggi swasta (PTS).

\section{C.2 Operasionalisasi Variabel}

Penelitian ini meliputi tiga variabel, yaitu kepuasan kerja, motivasi, dan kinerja dosen. Kepuasan kerja adalah perasaan dan penilaian dosen atas pekerjaannya, khususnya mengenai kondisi kerjanya, dalam hubungannya dengan apakah pekerjaannya mampu memenuhi harapan, kebutuhan dan keinginannya. Adapun indikator yang termasuk dalam variabel kepuasan kerja, adalah: (1) gaji, (2) kenyamanan terhadap pekerjaan, (3) kebanggaan terhadap lembaga, (4) penghargaan terhadap hasil kerja, (5) kebermaknaan tugas, (6) kesempatan untuk maju, (7) kewenangan mengatur sistem kerja, dan (8) umpan balik terhadap tugas itu sendiri.

Motivasi kerja merupakan keinginan seseorang dosen untuk melakukan sesuatu tindakan yang sifatnya mendorong, mengaktifkan, menggerakkan, dan mengarahkan perilaku dosen untuk mencapai tujuan yang berkaitan dengan pelaksanaan tugas-tugas tri dharma perguruan tinggi. Indikator motivasi kerja meliputi: (1) prestasi, (2) pengakuan, (3) tanggung jawab, (4) promosi, dan (5) pertumbuhan.

Kinerja dosen adalah sebagai suatu hasil kerja atau ukuran sukses bagi dosen di bidang tugasnya dengan menggunakan ukuran tertentu dan dievaluasi oleh orang tertentu pula. Adapun indikator yang termasuk dalam variabel kinerja dosen, adalah: (1) melaksanakan pendidikan dan pengajaran, (2) melaksanakan penelitian, (3) melaksanakan pengabdian kepada masyarakat.

\section{C.3 Metode Analisis Data}

Data dianalisis dengan menggunakan teknik analisis regresi linier berganda dengan rumus sebagai berikut:

Keterangan:

$$
\mathbf{Y}=\mathbf{a}+\mathbf{b} \mathbf{X}_{1}+\mathbf{b} \mathbf{X}_{2}+\mathbf{e}
$$

$\mathrm{Y}=$ Kinerja dosen

$\mathrm{a}=$ Konstanta

$\mathrm{b}=$ Koefisien regresi

$\mathrm{X}_{1}=$ Kepuasan kerja

$\mathrm{X}_{2}=$ Motivasi

$\mathrm{e}=$ error

\section{HASIL DAN PEMBAHASAN}

\section{D.1 Pengaruh Kepuasan Kerja terhadap Kinerja Dosen}

Hasil pengujian hipotesis pengaruh kepuasan kerja terhadap kinerja dosen Fakultas Ekonomi di perguran tinggi swasta di Makassar dapat dilihat sebagai berikut.

\section{Tabel 1}

Hasil Analisis Regresi Pengaruh Kepuasan Kerja terhadap Kinerja Dosen

\begin{tabular}{|l|c|c|c|c|}
\hline \multicolumn{1}{|c|}{ Model } & Koefisien & thitung $_{\text {Kriteria }}$ & p value & Krita \\
\hline Konstanta & $-13,926$ & & & \\
\hline Kepuasan Kerja $\left(\mathrm{X}_{1}\right)$ & 1,346 & 8,355 & 0,000 & Signifikan \\
\hline $\mathrm{R}^{2}$ & 0,426 & & & \\
\hline
\end{tabular}

Sumber: Output SPSS

Hasil analisis regresi ini diperoleh konstanta sebesar $-13,926$ dan koefisien kepuasan kerja (X1) sebesar 1,346 sehingga diperoleh model regresi:

$\mathrm{Y}=-13,926+1,346 \mathrm{X} 1$

Model tersebut menunjukkan bahwa setiap terjadi kenaikan atau penurunan kepuasan kerja sebesar $1 \%$ akan diikuti dengan kenaikan atau penurunan kinerja dosen sebesar 1,346\%. Koefisien regresi tersebut diuji kebermaknaannya menggunakan uji $t$ diperoleh thitung $=8,355$ dengan $p$ value $=$ $0,000<0,05$, berarti hipotesis 1 yang menyatakan ada pengaruh kepuasan kerja terhadap kinerja dosen perguruan tinggi swasta di Makassar diterima. Nilai $\mathrm{R}^{2}=0,426$, yang berarti bahwa kontribusi kepuasan kerja terhadap kinerja dosen perguruan tinggi swasta di Makassar sebesar 42,6\%. Kepuasan kerja berpengaruh positif dan signifikan terhadap kinerja dosen perguruan tinggi swasta di Makassar yaitu sebesar 42,6\%. Jadi 
42,6\% sebagai akibat dari indikatorindikator $\mathrm{X}_{1}$ dan di luar itu kemungkinan dipengaruhi oleh variabel-variabel lain yang tidak termasuk dalam penelitian ini.

Hal ini menunjukkan bahwa dosen semakin tinggi kepuasan kerjanya maka kinerjanya semakin tinggi pula, begitu sebaliknya semakin rendah kepuasan kerjanya maka semakin rendah pula kinerjanya. Kepuasan kerja memiliki pengaruh yang lebih dominan, seperti yang diungkapkan Robins (2006) bahwa kepuasan adalah sikap umum individu terhadap pekerjaannya. Seseorang dengan tingkat kepuasan kerja tinggi menunjukkan sikap yang positif terhadap kerja itu, seseorang yang tidak puas dengan pekerjaannya menunujukkan sikap yang negatif terhadap pekerjaannya. Hasil penelitian ini sesuai dengan penelitian Rumiyati (2007), Wartulas (2003) dan Rohadi (2005) yang menyatakan bahwa kepuasan kerja berpengaruh terhadap kinerja. Hal ini seperti yang diungkapkan oleh Kuswadi (2004) bahwa kepuasan kerja dapat membantu memaksimalkan kinerja dosen, dalam jangka panjang akan

Tabel 2

Distribusi Frekuensi Kepuasan Kerja Dosen Perguruan Tinggi Swasta di

Makassar

\begin{tabular}{|c|c|c|c|c|}
\hline No & Interval \% skor & Kriteria & Frekuensi & Persentase \\
\hline 1 & $85-100$ & Sangat tinggi & 0 & 0.0 \\
\hline 2 & $69-84$ & Tinggi & 12 & 11.9 \\
\hline 3 & $53-68$ & Cukup & 88 & 87.1 \\
\hline 4 & $37-52$ & Rendah & 1 & 1,0 \\
\hline 5 & $20-36$ & Sangat rendah & 0 & 0.0 \\
\hline & Jumlah & \multicolumn{3}{c}{100} \\
\hline
\end{tabular}

Sumber: Output SPSS

Tabel 2 memperlihatkan bahwa $87,1 \%$ dosen perguruan tinggi swasta di Makassar merasakan cukup puas berkaitan dengan pekerjaannya, hanya $11,9 \%$ tingkat kepuasan kerjanya dalam kategori tinggi. Hal ini menunjukkan bahwa

Tabel 3

Tingkat Kepuasan Kerja Dosen Perguruan Tinggi Swasta di Makassar

\begin{tabular}{|l|l|c|c|c|c|}
\hline No & \multicolumn{1}{|c|}{ Aspek Kepuasan } & Skor Total & Skor Ideal & \% skor & Kriteria \\
\hline 1 & Gaji & 1148 & 2020 & 56.83 & Cukup \\
\hline 2 & Kenyamanan & 1194 & 2020 & 59.11 & Cukup \\
\hline 3 & Kebanggan & 1235 & 2020 & 61.14 & Cukup \\
\hline 4 & Penghargaan & 943 & 2020 & 62.24 & Cukup \\
\hline
\end{tabular}

menghasilkan yaitu: (1) Dosen yang puas cenderung bekerja dengan kualitas yang lebih baik, (2) Dosen yang puas cenderung bekerja lebih produktif, (3) Dosen yang puas cenderung bertahan lebih lama dalam organisasi tempat dosen tersebut bekerja, dan (4) Dosen yang puas dapat bekerja sama dengan mahasiswa.

Kepuasan kerja merupakan sebuah penilaian antara kenyataan dengan yang diharapkan. Hasil penelitian tentang kepuasan kerja dosen perguruan tinggi swasta di cukup puas, terbukti rata-rata tingkat kepuasannya mencapai $62,50 \%$. Hal ini menunjukkan bahwa dalam hal melakukan pekerjaan berkaitan dengan pengajaran, penelitian dan pengabdian masyarakat, para dosen perguruan tinggi swasta di Makassar belum sepenuhnya dirasakan kepuasannya. Pada aspek-aspek tertentu, para dosen tersebut merasa puas, namun pada aspek lainnya belum dirasakan kepuasannya. Deskripsi tanggapan responden atas indikator-indikator kepuasan kerja dosen $\left(\mathrm{X}_{1}\right)$ diuraikan secra rinci sebagai berikut. Makassar menunjukkan hasil yang

\begin{abstract}
dari segi penggajian, kenyamanan, kebanggaan, kesempatan untuk maju, kewenangan mengatur sistem dan umpan balik masih dirasakan cukup tingkat kepuasannya. Lebih jelasnya dapat dilihat pada tabel 3 .
\end{abstract}




\begin{tabular}{|l|l|c|c|c|c|}
\hline 5 & Kebermaknaan tugas & 1407 & 2020 & 69.65 & Tinggi \\
\hline 6 & Kesempatan untuk maju & 1347 & 2020 & 66.68 & Cukup \\
\hline 7 & Kewenangan mengatur sistem & 1222 & 2020 & 60.50 & Cukup \\
\hline 8 & Umpan balik & 972 & 2020 & 64.16 & Cukup \\
\hline
\end{tabular}

Sumber: Output SPSS

Kepuasan tertinggi lebih banyak dirasakan oleh dosen berkaitan dengan kebermaknaan tugas, artinya mereka cenderung puas dengan apa yang dilakukan sebagai pengajar untuk menciptakan sebuah pembelajaran yang kondusif. Namun dari segi lainnnya seperti gaji, kenyamanan, kebanggaan, penghargaan, kesempatan untuk maju, kewenangan mengatur sistem dan umpan balik belum dirasakan secara puas. Kebermaknaan tugas lebih menyangkut pada intern dosen yaitu menyangkut pekerjaan yang setiap dosen memiliki karakteristik sendiri-sendiri dalam melakukan pengajaran, namun aspek lainnya terbentuk karena sebuah sistem yang berjalan sesuai kebijakankebijakan dari akademi. Kondisi

Tabel 4

Hasil Analisis Regresi Pengaruh Motivasi Kerja terhadap Kinerja Dosen

\begin{tabular}{|l|c|c|c|c|}
\hline \multicolumn{1}{|c|}{ Model } & Koefisien & thitung $_{\text {h }}$ & p value & Kriteria \\
\hline Konstanta & 28,714 & & & \\
\hline Motivasi Kerja $\left(\mathrm{X}_{2}\right)$ & 0,665 & 4,585 & 0,000 & Signifikan \\
\hline $\mathrm{R}^{2}$ & 0,163 & & & \\
\hline
\end{tabular}

Sumber: Output SPSS

Hasil analisis regresi ini diperoleh konstanta sebesar 28,714 dan koefisien motivasi kerja $\left(\mathrm{X}_{2}\right)$ sebesar 0,665 sehingga diperoleh model regresi:

$\mathrm{Y}=28,714+0,665 \mathrm{X}_{2}$

Model tersebut menunjukkan bahwa setiap terjadi kenaikan atau penurunan motivasi kerja sebesar $1 \%$ akan diikuti dengan kenaikan atau penurunan kinerja dosen sebesar $0,665 \%$. Koefisien regresi tersebut diuji kebermaknaannya menggunakan uji $t$ diperoleh thitung $=4,585$ dengan $p$ value $=$ $0,000<0,05$, berarti hipotesis 2 yang menyatakan ada pengaruh motivasi kerja terhadap kinerja dosen perguruan tinggi swasta di Makassar diterima. Nilai $R^{2}=0,163$, yang berarti bahwa kontribusi motivasi kerja terhadap kinerja dosen perguruan tinggi swasta di Makassar sebesar 16,3\% sebagai tersebut lebih banyak dipengaruhi oleh kebijakan pengelola masingmasing perguruan tinggi swasta di Makassar.

\section{D.2 Pengaruh Motivasi Kerja terhadap Kinerja Dosen}

Pengujian hipotesis yang menyatakan ada pengaruh motivasi kerja terhadap kinerja dosen dapat dilihat dari hasil analisis regresi seperti pada tabel 4 . akibat indikator-indikator $\mathrm{X}_{2}$ dan di luar itu kemungkinan dipengaruhi oleh variabel-variabel yang tidak termasuk dalam penelitian ini.

Banyak faktor yang mempengaruhi kinerja dosen, namun dorongan atau motivasi kerja memiliki peranan yang penting dalam pelaksanaan tri dharma perguruan tinggi. Suatu kinerja pasti diawali oleh niat dan niat itu lah merupakan suatu motor penggerak seorang dosen melakukan suatu kegiatan pengajaran, penelitian, dan pengabdian kepada masyarakat.

Berdasarkan hasil analisis regresi menunjukkan bahwa semakin tinggi persepsi dosen tentang motivasi kerja maka semakin tinggi pula kinerja dosen. Sebaliknya semakin rendah motivasi kerjanya maka semakin rendah pula kinerjanya. Seperti 
yang diungkapkan Winardi (2004) bahwa motivasi merupakan sesuatu kekuatan yang ada dalam diri manusia, yang dapat dikembangkan sendiri atau dikembangkan oleh sejumlah kekuatan luar, pada intinya berkisar sekitar imbalan moneter dan non moneter, yang dapat mempengaruhi hasil kinerjanya secara positif dan secara negatif, hal mana tergantung pada situasi dan kondisi dari orang yang bersangkutan.

Hasil penelitian ini sesuai dengan penelitian Rumiyati (2007), Wartulas (2003), dan Rohadi (2005) yang menyatakan bahwa terdapat pengaruh antara motivasi kerja terhadap kinerja dosen. Motivasi kerja seorang dosen sangat penting untuk peningkatan kinerja dosen, dengan motivasi yang dimiliki maka dosen dapat lebih meningkatkan mutunya dalam melaksanakan tugas keprofesionalisme dan melaksanakan kewajiban pendidikan dan pengajaran. Dengan demikian hasil penelitian ini mendukung kajian empiris mengenai pengaruh motivasi kerja terhadap kinerja dosen perguruan tinggi swasta di Makassar.

Hasil analisis deskriptif menunjukkan bahwa motivasi kerja dari 101 responden dosen swasta di kota Makassar tergolong cukup dengan rata-rata sebesar $62,4 \%$. Motivasi kerja merupakan faktor yang mempengaruhi kinerja dosen.

Motivasi yang dimaksud adalah suatu dorongan mental yang muncul dari dalam dan luar diri dosen untuk melaksanakan tugas. Duncan dalam Uno (2007) mengemukakan motivasi kerja berkaitan dengan dorongan yang muncul dari diri seseorang untuk melakukan tugas secara keseluruhan berdasarkan tanggung jawab masing-masing (dosen). Bagi seorang dosen, tugas dan tanggung jawab tersebut terlihat dalam melaksanakan tri dharma perguruan tinggi. Dosen yang mempunyai motivasi kerja yang tinggi maka akan menghasilkan kinerja yang tinggi pula.

Herzberg dalam Hasibuan (2003) menyatakan bahwa orang dalam melaksanakan pekerjaannya dipengaruhi oleh dua faktor yang merupakan kebutuhan yaitu faktor pemeliharaan dan faktor motivator. Faktor pemeliharaan yang berhubungan dengan hakikat manusia yang ingin memperoleh ketenteraman badaniah, sedangkan faktor motivator yang menyangkut kebutuhan psikologis seseorang yaitu perasaan sempurna dalam melakukan pekerjaan. Faktor-faktor yang mempengaruhi motivasi yaitu; prestasi, pengakuan, tanggung jawab, promosi, dan pertumbuhan.

Deskripsi tanggapan responden atas indikator-indikator motivasi kerja dosen $\left(\mathrm{X}_{2}\right)$ diuraikan secara rinci sebagai berikut.

Tabel 5

Distribusi Frekuensi Motivasi Kerja Dosen Fakultas Ekonomi Perguruan Tinggi Swasta di Makassar

\begin{tabular}{|c|c|c|c|c|}
\hline No & Interval \% skor & Kriteria & Frekuensi & Persentase \\
\hline 1 & $85-100$ & Sangat tinggi & 0 & 0.0 \\
\hline 2 & $69-84$ & Tinggi & 9 & 8.9 \\
\hline 3 & $53-68$ & Cukup & 84 & 83.2 \\
\hline 4 & $37-52$ & Rendah & 8 & 7.9 \\
\hline 5 & $20-36$ & Sangat rendah & 0 & 0.0 \\
\hline & Jumlah & & & \\
\hline
\end{tabular}

Sumber: Output SPSS

Tabel 5 memperlihatkan bahwa $83,2 \%$ dosen perguruan tinggi swasta di Makassar memiliki motivasi cukup bahkan 7,9\% memiliki motivasi rendah, hanya 8,9\% dalam kategori tinggi. Hal ini menunjukkan bahwa dorongan dalam bekerja baik dari dalam diri dosen maupun di luar diri dosen yaitu berasal dari lembaga pendidikan tempat mereka bekerja tergolong cukup, karena dorongan yang tidak terlalu kuat berkaitan dengan prestasi, pengakuan, tanggung jawab, promosi dan pertumbuhan. Ditunjukkan pula 
dari rata-rata persentase skor untuk aspek motivasi kerja dalam kategori cukup. Aspek paling tinggi pada motivasi yang berkaitan dengan tanggung jawab dosen sebagai pengajar, diikuti dorongan dalam promosi jabatan, pertumbuhan dan pengakuan, sedangkan aspek yang paling rendah adalah dorongan untuk peningkatan prestasi.

\section{D.3 Pengaruh Kepuasan Kerja dan Motivasi Kerja terhadap Kinerja Dosen}

Pengujian hipotesis yang menyatakan ada pengaruh motivasi dan kepuasan kerja terhadap kinerja dosen dapat dilihat dari hasil analisis regresi seperti pada tabel 6.

Tabel 6

Analisis Regresi Pengaruh Kepuasan Kerja dan Motivasi terhadap Kinerja Dosen

\begin{tabular}{|l|c|c|c|c|}
\hline \multicolumn{1}{|c|}{ Model } & Koefisien & thitung $_{\text {h }}$ & p value & $\mathbf{R}^{\mathbf{2}}$ \\
\hline Konstanta & $-21,860$ & & & \\
\hline Motivasi Kerja $\left(\mathrm{X}_{2}\right)$ & 0,286 & 38,518 & 0,0 & 0,480 \\
\hline Kepuasan Kerja $\left(\mathrm{X}_{1}\right)$ & 1,188 & & & \\
\hline
\end{tabular}

Sumber: Output SPSS

Hasil analisis regresi ini diperoleh konstanta sebesar $-21,860$ dan koefisien motivasi $\left(\mathrm{X}_{2}\right)$ sebesar 0,286 sedangkan kepuasan kerja $\left(\mathrm{X}_{1}\right)$ sebesar 1,188 sehingga diperoleh model regresi:

$\mathrm{Y}=-21,860+1,188 \mathrm{X}_{1}+0,286 \mathrm{X}_{2} . .(3)$

Model tersebut menunjukkan bahwa setiap terjadi kenaikan atau penurunan motivasi kerja dengan mengontrol kepuasan kerja sebesar $1 \%$ akan diikuti dengan kenaikan atau penurunan kinerja dosen sebesar 0,286\%, sebaliknya setiap terjadi penurunan atau kenaikan kepuasan kerja $1 \%$ dengan mengontrol motivasi kerja akan diikuti dengan kenaikan atau penurunan kinerja sebesar 1,188\%. Secara simultan, hipotesis ini diuji kebermaknaannya menggunakan uji $\mathrm{F}$ diperoleh nilai $\mathrm{F}$ hitung $=38,518$ dengan $p$ value $=0,000<0,05$ berarti hipotesis yang menyatakan bahwa secara simultan kepuasan kerja dan motivasi berpengaruh terhadap kinerja dosen perguruan tinggi swasta di Makassar diterima. Nilai $R^{2}=0,480$ berarti bahwa kontribusi motivasi dan kepuasan kerja terhadap kinerja dosen perguruan tinggi swasta di Makassar sebesar 48\%, sedangkan sisanya sebesar $52 \%$ dipengaruhi oleh variabel lain di luar penelitian ini. Jadi, semakin tinggi kepuasan kerja dan motivasi kerja dosen, maka akan semakin tinggi pula kinerjanya, demikian pula sebaliknya.

Hasil analisis tersebut di atas menggambarkan bahwa motivasi kerja yang semakin tinggi diikuti dengan kepuasan kerja yang semakin tinggi pula, akan mempengaruhi kinerja dosen secara lebih optimal, begitu juga sebaliknya. Motivasi merupakan tenaga penggerak untuk melaksanakan suatu tindakan (kinerja) dan diikuti dengan kepuasan yang tinggi terhadap halhal yang berkaitan dengan pekerjaannya maka akan mendorong untuk menunjukkan kinerja secara lebih baik.

Kepuasan kerja dan motivasi kerja dosen merupakan dua faktor diantara banyak faktor yang mempengaruhi kinerja dosen perguruan tinggi swasta di Makassar. Dengan demikian maka sebaiknya dosen dalam melakukan kinerja sesuai dengan tujuan tri dharma perguruan tinggi meliputi tiga komponen yaitu pelaksanaan pendidikan dan pengajaran, penelitian, dan pengabdian kepada masyarakat tersebut akan terwujud dengan baik apabila ada dorongandorongan baik dari dalam diri maupun dari luar diri dosen serta adanya kepuasan yang mendalam terhadap hal-hal yang berkaitan dengan pekerjaan seperti gaji, kenyamanan, kebanggaan, penghargaan, kebermaknaan tugas, kesempatan untuk maju, kewenangan mengatur sistem sendiri, dan umpan balik yang pada akhirnya kinerja dosen menjadi optimal. 


\section{E. KESIMPULAN}

Berdasarkan hasil penelitian kepuasan kerja, motivasi kerja, dan kinerja dapat diambil kesimpulan sebagai berikut:

1. Hasil pengujian hipotesis 1 menghasilkan persamaan regresi: $\mathrm{Y}=-13,926+1,346 \quad \mathrm{X}_{2}$ berarti hipotesis 1 yang menyatakan ada pengaruh kepuasan kerja terhadap kinerja dosen perguruan tinggi swasta di Makassar diterima. Nilai $R^{2}=$ 0,426, yang berarti bahwa kontribusi kepuasan kerja terhadap kinerja dosen perguruan tinggi swasta di Makassar sebesar 42,6\%. Kepuasan kerja berpengaruh positif terhadap kinerja dosen perguruan tinggi swasta di Makassar yaitu sebesar $42,6 \%$. Hal ini menunjukkan bahwa dosen semakin tinggi kepuasan kerjanya maka kinerjanya semakin tinggi pula, begitu sebaliknya semakin rendah kepuasan kerjanya maka semakin rendah pula kinerjanya.

2. Hasil pengujian hipotesis 2 menghasilkan persamaan regresi: $\mathrm{Y}=28,714+0,665 \mathrm{X}_{1}$ berarti hipotesis 2 yang menyatakan ada pengaruh motivasi kerja terhadap kinerja dosen perguruan tinggi swasta di Makassar diterima. Nilai $R^{2}=0,163$, yang berarti bahwa kontribusi motivasi kerja terhadap kinerja dosen perguruan tinggi swasta di Makassar sebesar $16,3 \%$. Hal ini menunjukkan bahwa semakin tinggi persepsi dosen tentang motivasi kerja maka semakin tinggi pula kinerja dosen, sebaliknya semakin rendah motivasi kerjanya maka semakin rendah pula kinerjanya.

3. Berdasarkan hasil analisis regresi berganda, pengaruh kepuasan kerja dan motivasi kerja terhadap kinerja dosen dihasilkan persamaan: $\mathrm{Y}=$ $21,860+1,188 \mathrm{X}_{1}+0,286 \mathrm{X}_{2}$ berarti hipotesis yang menyatakan bahwa secara simultan kepuasan kerja dan motivasi berpengaruh terhadap kinerja dosen perguruan tinggi swasta di Makassar diterima. Nilai $R^{2}=0,480$, berarti bahwa kontribusi motivasi dan kepuasan kerja terhadap kinerja dosen perguruan tinggi swasta di Makassar sebesar $48 \%$, sedangkan sisanya sebesar $52 \%$ dipengaruhi variabel lain di luar penelitian. Jadi, semakin tinggi motivasi kerja dan semakin tinggi kepuasan kerja dosen, maka akan semakin tinggi pula kinerjanya.

\section{DAFTAR PUSTAKA}

Syukra, A. dan Sanusi, R. 2006. Persepsi Perilaku Kepemimpinan sebagai Warga Organisasi dan Kinerja Dosen Politeknik Kesehatan Padang Sumetara Barat. Dalam http://www. kmpk.ugm.ac.id.Diakses pada hari Selasa, tanggal 25 Maret 2014.

Davies, A. dan Cline, T. W. 2005. A Consumer Behavior Approach to Modeling Monopolistic Competition. Journal of Economic Psychology (26): 797 - 826.

Hasibuan, H. dan Malayu, S.P. 2003. Organisasi \& Motivasi. Jakarta: PT Bumi Aksara.

Isham, A. 2008. Pengaruh Keadilan Prosedural, Kepuasan Kerja, dan Perilaku Anggota Organisasi terhadap Kinerja Dosen Universitas Islam Negeri Syarif Hidayatullah Jakarta. Disertasi. Jakarta.

Komara, A. H. 2007. Pengaruh Kepemimpinan, Budaya Organisasi, Strategi Organisasi dan Motivasi terhadap Kinerja Pegawai. Disertasi, Ilmu Manajemen Program Pascasarjana FE Universitas Brawijaya. Malang.

Kuvaas, Baard. 2006. Work Performance, Affective Commitment, and Work Motivation: The Roles of Pay Administration and the Pay Level. Journal of Organizational Behaviour, 2006 Vol.. 27, pp. 365-385.

Luthans, F. 2005. Organizational Behavior. Ninth Edition. New 
York: McGraw-Hill International Editions.

Ramaseshan, B., Leslie, S.C.Y., dan Jae H. P. 2006. Power, Satisfaction and Relationship Commitment in Chinese StoreTenant Relationship and Their Impact on Performance. Journal of Retailing; Vol. 82 Number 1; 2006; pp. 63-70.

Robbins, S. P. 2007. Perilaku Organisasi (Terjemahan PT Indeks). Edisi Kesepuluh. Edisi Lengkap. Cetakan Kedua. New Jersey: Prentice-Hall.

Rohadi. 2005. Pengaruh Motivasi, Kepuasan Kerja, dan Komitmen Organisasi pada Kinerja Guru pada Kinerja Guru Bantu SMA di Kabupaten Kendal. Tesis. Semarang: PPs Universitas Negeri Semarang.

Rumiyati. 2006. Pengaruh Kepuasan Kerja dan Motivasi Kerja terhadap Kinerja Dosen Fakultas Kedokteran UKI Jakarta. http://pasca.uns.ac.id/mod.phm od=publisher\&op=viewarticle\&art id=144 (17 November 2007).

Siagian, S. P. 2005. Manajemen Sumber Daya Manusia. Cetakan Kesepuluh. Jakarta: Bumi Aksara.

Sulistiyani, A. T. dan Rosidah. 2005. Manajemen Sumber Daya Manusia: Konsep, Teori dan Pengembangan Dalam Konteks Organisasi Publik. Cetakan Pertama. Yogyakarta: Graha Ilmu.

Triton, P.B. 2005. Paradigma Baru Manajemen Sumber Daya Manusia: Kunci Sukses Meningkatkan Kinerja, Produktivitas, Motivasi, dan Kepuasan Kerja. Cetakan Pertama. Yogyakarta: Tugu.

Uno, H. B. 2007. Teori Motivasi \& Pengukurannya Analisis di Bidang Pendidikan. Jakarta: PT Bumi Aksara.

Winardi. 2004. Motivasi Pemotivasian Dalam Manajemen. Jakarta: PT Raja Grafindo Pesada. 